\title{
自動車整備に関する実習教育における一試案 （エンジン指圧線図の実習教育への利用）
}

An Experimental Method on Practice Education of Automobile Maintenance (Using Engine Indicator Diagram for Practice Education)

\section{二村 幸 孝* 逸 見 勤唠 沼 義一** Yoshitaka FUTAMURA Tutomu HENMI Yoshikazu SUGANUMA}

\section{1. まえがき}

最近の自動車の進歩は著しく，各種の制御装置が 付加されることにより，自動車各部の最適制御がな され，乗心地，安全性，耐久性などの性能は非常に 向上してきている。特にマイコンによる制御は，そ の正確さ，精密さにおいて従来の機械的制御に比べ 格段にすぐれている。

このような状況にあって，自動車整備に関する実 習教育においては，自動車の高度化に対応した技術 教育が必要となってきている。すなわち，自動車の メインテナンス技術は，自動車の進歩に応じて高度 化され，常に変革を迫られていると同時に，学校教 育あるいは企業内教育等においても常に技術革新へ の対応が必要である。例えは，従来のメインテナン スには使用されることのなかったシンクロスコープ 等の機器は，自動車各部に現れるトラブルの諸現象 を，いつかの異なったプローブあるいはセンサー を用いることによって汎用的に使用することが可能 であり，またその他の自動車メインテナンスにおい て広く応用することができる。

そこで，本報では，内燃機関の基本的要素である

※ 高山短期大学自動車工業学科 講師

※同

Takayama Jr. College

昭和61年度 工業教育研究講演会 (1986-12-6)

において発表
燃焼の観察を対象として，シンクロスコープを利用 することを試み，教育用として実用的であるかどう かの考察を行った。通常，実験室内で燃烧解析に用 いられる指圧線図を，ごく簡易的に作成しエンジン 内部の現象を直接的に理解させることによってエン ジンに対する理解と興味を深め,より教育効果をあ げようと試みた。

\section{2. エンジン指圧線図の教育的効果}

従来，メインテナンスの目的から，ガソリンエン ジンの稼動状態を把握する場合，その回転速度，点 火系統及び排気ガス等から良否判定を行っている。 また，点火プラグれに圧力ゲージを挿入し点火は行 わないで，始動装置によりクランキングを行い，シ リンダ内の気密の観察等を行っている。しかし, 直 接的にエンジンが稼動中の燃燒状態を観測すること はできないため，電気系統などの間接的な情報から 燃焼状態の不良を想定し故障診断を行っている。一 方，実験室内で使用される特殊なエンジンでは，然 焼解析等の目的から高精度の指圧計の燃焼室内への 設置あるいは燃焼の高速度撮影が行われている。こ れらをより簡易的な方法でメインテナンス技術に応 用し，プローブ挿入孔等のシリンダヘッドへの特殊 な改造を施すことなくエンジン指圧線図を作成し， 具体的な压力変化を観察することで然焼に対する理 解を補助できる。また，故障時における燃焼状態の 変化等も，識別可能であれは，故障垷象をより明確 
に把握することができる。さらに，エンジンメイン テナンス上で最も重要な要素である燃焼中の生力変 化をシンクロスコープ等に写しだすことにより，学 生に対する動機付けが期待され教育効果も見迅まれ る。

\section{3. エンジン指圧線の観測}

\section{1 ストレーンゲージ式指圧計}

ストレーンゲージ式の欧力計は，ピエソ式ととも にエンジン指压計として広く用いられており，シリ ンダヘッドにプローブ穴を作成し，指圧計を固定す るもので，その出力サンプルを図 1 に示す。通常, クランクシャフトの回転角及び点火プラグへの点火 信号と同時に指王線は記録される。図10a は正常 時の燃焼を示しており，また $\mathrm{b} は$ 点火時期が少し早 まった場合で，波形の乱れが見受けられ，異常燃焼 を生じているのが分かる。このような通常とは異な った波形パターンを実際の使用過程車において測定 し判別することができれば，使用過程中において生 じる様々な故障現象（例えば，ビストンリングや吸 排気バルフ等の不良)をより直接的に判断すること ができる。

\section{2 簡易型指圧計}

図 2 はある乗用車エンジンの点火プラグ孔に装着 されているセラミックの压電素子で，その機能は燃 焼室内の異常燃焼を感知 $し$ ，その圧力信号を車載の マイコンに送っている。そこで，この圧電素子を図 3 に示すような測定システムを用いて汎用的に他の エンジンにも装着し，それらの信号を観測して解析

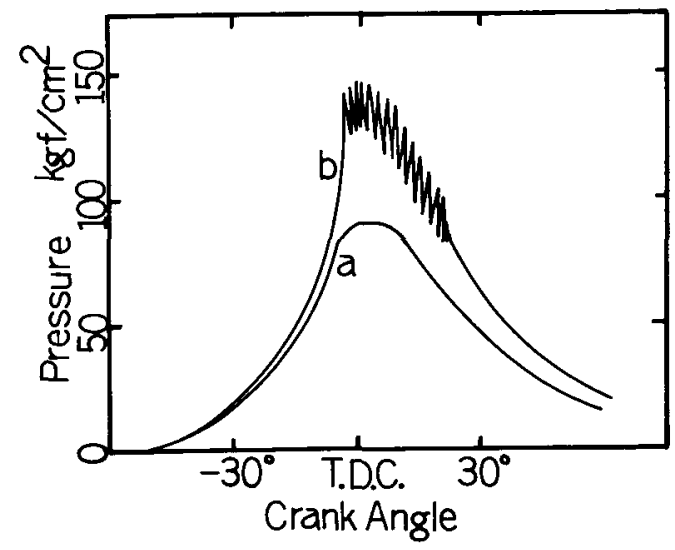

図 1 指圧線図出力サンプル ( 4 気筒 4 サイクルエンジン)
することにより，エンジン稼動中の故障探究が可能 である。

\section{4. まとめ}

自動車整備に関する技術教育においては，自動車 の技術革新に対応して常に教育内容の刷新を行う必 要があり，エンジン指圧線の観測は表面的な解説だ けでは㧿えにくいエンジン内部の燃烤状態を多角的 に理解させることで，より教育効果を期待できると 予想される。

今回の報告では，簡易なエンジン指王計により汎 用的な測定システムの装置を設定し基檚的な事項を 確認して，実習教育用として充分に使用可能である ことが分かった。今後，実例サンブルを多く記録し 様々な故障時の指压線図のパターンを収集したい。

\section{参考文献}

1）レパード整備要領書，日産自動車，昭 $60 ， 50$

2）ソニーテクトロニクス編；波形観測，ラジオ技術社， 昭 60

3）二村他；自動車整備に関する実習教育のパソコン利用 ; 日本工業教育協会誌， 34 巻- 3 号, 昭 61

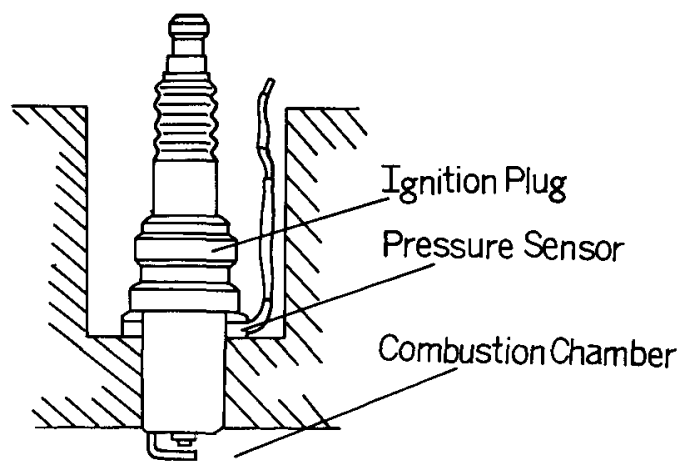

図 2 セラミック氏カ地センサー （点火プラグワッシャ式）

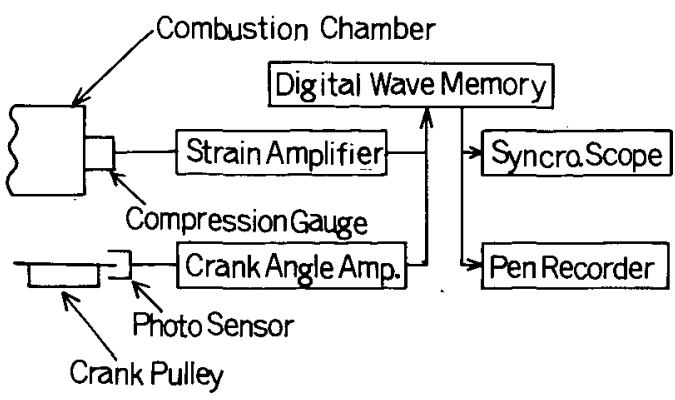

図 3 エンジン指厈計测定システム 